FILOZOFIA

Roč. 75,2020 , č. 7

DOI: https://doi.org/10.31577/filozofia.2020.75.7.6

\title{
K JEDNÉMU POKUSU O EVOLUČNÉ VYSVETLENIE MORÁLKY
}

STANISLAV SPODNIAK, Filozofická fakulta Univerzity Mateja Bela v Banskej Bystrici, Katedra filozofie, Banská Bystrica, SR

SPODNIAK, S.: On One Attempt to Evolutionary Explain Morals FILOZOFIA, 75, 2020, No 7, pp. $584-595$

The aim of the paper is to critically analyse one of the many attempts to explain the origin of our morality using evolutionary theory. Specifically, this paper deals with an anthropological theory presented by Curry, Mullins and Whitehouse in which they predict existence of seven universal moral patterns. They assume that these patterns and morality as such are a biological and cultural response to a need to establish cooperation in human societies. Several weaknesses of their moral theory are pointed out with the conclusion that their theory may be able to explain why it is advantageous with respect to natural selection to prefer certain behaviour, but not why we attribute moral evaluations to a given behaviour. Therefore, their theory does not provide a reason to regard moral elements analysed in the paper as evolutionarily acquired adaptations.

Keywords: Evolutionary psychology - Moral norms - Morality as cooperation Theory of evolution

\section{Úvod}

Predpoklad, že Darwinova teória evolúcie nie je užitočná len z hl'adiska objasnenia genézy našich fyzických znakov, ale môže byt' nápomocná aj pri explikácii aspoň niektorých prvkov nášho správania a morálky, vyvoláva v súčasnosti početné diskusie. Na základe tohto predpokladu sa sformoval relatívne nový vedný odbor evolučnej psychológie, no osvojili si ho aj mnohí predstavitelia iných vedných odborov a filozofických disciplín. Zatial' čo vedci dúfajú, že pomocou evolučnej teórie dokážeme lepšie vysvetlit', prečo sa v niektorých typických situáciách (napríklad výber partnera, starostlivost' o diet'a, postoj k cudzincom) správame tak, ako sa správame, a prečo sú mnohé naše normy (takmer) univerzálne, niektorí fillozofi sú presvedčení, že by nám tento prístup mohol pomôct' pozriet' sa na niektoré otázky - najmä z oblasti etiky z novej perspektívy.

Jeden z mnohých problematických bodov diskusií venovaných tejto problematike tkvie v tom, že v evolučnej biológii neexistuje všeobecná zhoda na tom, čo je v procese prírodného výberu selektované (najčastejší kandidáti sú gény, genotypy 
alebo celé skupiny). V tomto článku venujem pozornost' pokusu o vysvetlenie pôvodu morálky, ktorý vychádza z génocentrickej (gene-centred) verzie evolučnej teórie, a to preto, lebo s takouto verziou evolučnej teórie máme možnost' stretnút' sa vo filozofickej literatúre najčastejšie. Konkrétne ide o teóriu morálky s názvom „morálka ako spolupráca“, ktorú ponúka trojica antropológov Curry, Mullins a Whitehouse (2019). Ciel’om článku je poukázat' na to, že teória, ktorú títo autori ponúkajú, síce vysvetl'uje, prečo je z hl'adiska toho, aby naše gény neboli prírodným výberom eliminované, výhodné uprednostňovat' určité správanie, ale nie to, prečo danému správaniu pripisujeme pozitívne morálne hodnotenia. Teória týchto autorov nám preto neponúka dôvod, aby sme sa na dané prvky morálky pozerali ako na evolučným procesom nadobudnuté adaptácie.

\section{Evolučno-psychologické východiská}

E. O. Wilson v sedemdesiatych rokoch minulého storočia založil disciplínu nazývanú sociobiológia, ktorej zámerom bolo vychádzajúc z evolučnej teórie študovat' biologickú podmienenost' sociálneho správania (Wilson 2000, 31). ${ }^{1}$ Výskumný program sociobiológie bol od svojho vzniku podrobený ostrej kritike, ${ }^{2}$ no napriek tomu nezanikol, ale existuje dodnes transformovaný do relatívne nového odboru evolučnej psychológie (Joyce 2006, 5). ${ }^{3}$ Aj ked', ako upozorňuje Kennair (2002, 20), medzi sociobiológiou a evolučnou psychológiou existuje niekol'ko rozdielov. Jeden z týchto rozdielov spočíva v tom, že zatial' čo sociobiológia zvyčajne skúmala prejavy adaptability organizmov, evolučná psychológia kladie dôraz na skúmanie adaptácií. ${ }^{4}$

Podla Kennaira $(2002,20)$ zatial' čo výraz „adaptabilita“ označuje schopnost' prispôsobit' sa prostrediu, v ktorom organizmus žije, adaptácie sú evolučným procesom vyselektované produkty schopnosti prispôsobit' sa, ktoré organizmus zdedil po svojich predkoch. ${ }^{5}$ Vd'aka tomu, že sa prostredie mení, to, čo bolo adaptabilné v minulosti, nemusí byt' adaptabilné v súčasnosti. Známym ilustratívnym príkladom je, že zatial' čo v minulosti, ked' zdroje potravy boli ovel'a obmedzenejšie ako dnes, bolo adaptabilným správaním skonzumovat' čo najviac potravín, ked’ sme k tomu mali prí-

\footnotetext{
${ }^{1}$ Sociobiologické stanovisko, podl'a ktorého možno biologické koncepcie aplikovat' na psychologické a sociálne fenomény, obhajuje Sýkora (1999). Pre kritiku Sýkorovej pozície pozri Sedová (2000) a Kanovský (2000).

${ }^{2}$ Najčastejšie mu vyčítali redukcionizmus a genetický determinizmus. Ciel’om tohto článku nie je zhodnotit', či oprávnene alebo neoprávnene.

${ }^{3}$ Za klasické dielo evolučnej psychológie možno pokladat' Barkow, Cosmides, Tooby (1992).

${ }^{4}$ Za zmienku stojí, že podl’a E. O. Wilsona $(2000,10)$,evolučná psychológia“ je len novší názov pre sociobiológiu.

${ }^{5}$ Kennair $(2002,20)$ rozlíšenie medzi prejavmi adaptability a adaptáciami preberá z knihy Barkow, Cosmides, Tooby $(1992,148-150)$.
} 
ležitost', z dnešného pohl'adu túto zdedenú adaptáciu len t’ažko možno považovat' zároveň za adaptabilnú, ked’že $\mathrm{v}$ súčasnosti žijeme $\mathrm{v}$ prostredí, $\mathrm{v}$ ktorom je potrava ovel'a dostupnejšia, a preto tendencie skonzumovat' čo najviac potravín prispievajú $\mathrm{k}$ rozširovaniu civilizačných chorôb. ${ }^{6}$

Podl'a Kennairovej interpretácie prínos evolučnej psychológie je teda v tom, že začala brat' do úvahy, že mnohé súčasné javy môžu byt' len vedl'ajším produktom evolučného vývoja. ${ }^{7}$ Uvedomenie si tejto skutočnosti bolo predpokladom pre vznik diskusie o tom, či je aj morálka adaptáciou, alebo „len“ vedl'ajším produktom nadobudnutia nejakej inej adaptácie, pričom však v súčasnosti prevažuje stanovisko, podl’a ktorého je morálka predsa len nejakou formou adaptácie (Fraser 2010, 224). ${ }^{8} \mathrm{Z}$ tohto dôvodu som sa aj ja $\mathrm{v}$ tejto práci rozhodol venovat' teórii morálky, ktorá zapadá do názorového tábora, podla ktorého sa morálka postupne vyvinula ako naša adaptácia, ktorá plnila - a stále aj plní - dôležitú funkciu, ktorou je zabezpečovanie spolupráce $\mathrm{v}$ rámci spoločenstva.

Takisto treba brat' do úvahy, že v evolučnej biológii neprevláda konsenzus o tom, čo je v procese prírodného výberu selektované. Zásluhou Richarda Dawkinsa (2003) a jeho populárnej knihy Sobecký gén, ktorú do češtiny preložil Vojtěch Kopský, je najznámejšia pozícia, podl’a ktorej sú procesom prirodzeného výberu selektované gény. Pinker ponúka výstižný popis mechanizmov, na základe ktorých majú evolúciou selektované gény ovplyvňovat' naše myslenie: „Mysel' je produktom mozgu; konkrétne, mozog spracúva informácie a myslenie je ako vykonávanie počítačového výpočtu. Mysel' je organizovaná v moduloch alebo v mentálnych orgánoch, pričom každý z nich disponuje špeciálnym dizajnom, ktorý ho predurčuje na to, aby vynikal $\mathrm{v}$ špecifickej oblasti interakcie so svetom. Základná stavba modulov je určená našou genetickou výbavou. Ich fungovanie bolo prírodným výberom nastavené tak, aby našim predkom pomáhali riešit' problémy, s ktorými sa počas vel'kej časti evolučného vývoja vo svojich životoch lovcov a zberačov stretávali. Problémy, s ktorými sa naši predkovia stretávali, boli čiastkovými problémami jedného vel'kého problému ich génov - maximalizovat' počet kópií, ktoré sa prenesú do nasledujúcej generácie“ (Pinker $1998,21){ }^{9}$

\footnotetext{
${ }^{6}$ Pre podrobnejšie objasnenie tohto fenoménu z evolučno-psychologickej perspektívy pozri Bellisari (2008).

${ }^{7}$ Tieto vedl'ajšie produkty sa zvyknú označovat' aj ako spandrle. K spandrlom pozri Gould, Lewontin (1979).

${ }^{8}$ Freser medzi zástupcov pozície, podl’a ktorej je morálka adaptáciou, zarad’uje Ruse (1998), Joyce (2006) a Street (2006). Najznámejším predstavitel’om tábora, podl'a ktorého je morálka vedl'ajším produktom evolučného vývoja, je Jesse Prinz, ktorý toto stanovisko vyjadruje napríklad v Prinz $(2008,368)$.

${ }^{9} \mathrm{~V}$ mnohom podobnú charakteristiku východísk evolučnej psychológie ponúkajú aj Sýkora (1999, 391) a Popper $(2003,12)$.
} 
Voči Dawkinsovej génocentrickej verzii evolučnej teórie však existujú aj alternatívy. Napríklad podl’a Mayra $(2002,140)$ selekcia neprebieha na úrovni génov, ale na úrovni genotypu, ked’že miera, do akej sa jedinec prispôsobí prostrediu, má závisiet' od toho, ako jeho jednotlivé gény navzájom interagujú. Podl’a Wilsona (2008, 380) sa zasa prírodný výber, ktorý sa odohráva na úrovni génov, deje aj na úrovni skupín, a tak má byt' zrejmé napríklad to, že skupina, v ktorej prevládajú členovia, ktorí k zdrojom pristupujú šetrne, má väčšiu šancu nebyt' prirodzeným výberom eliminovaná v porovnaní so skupinou, ktorej členovia zdrojmi plytvajú.

Samostatnú kategóriu predstavuje teória podvojnej dedičnosti (dual inheritance theory), ktorá predpokladá, že dochádza ku génovo-kultúrne koevolúcii. ${ }^{10}$ Podl’a tejto teórie sme produktmi tak genetickej, ako aj kultúrnej evolúcie, pričom oba tieto evolučné procesy majú prebiehat simultánne. Podla Boyda a Richersona $(2005,4)$ napríklad súčasnými rozvinutými jazykmi disponujeme vd’aka tomu, že nás evolúcia prebiehajúca na genetickej úrovni vybavila schopnost'ami počut', hovorit' a naučit' sa jazyk, čo zas viedlo k tomu, že ,existencia primitívnych jazykov podmienila vznik kultúrneho prostredia, v ktorom platí, že lepšie jazykovo vybavení jedinci disponujú výhodou, ktorá im umožňuje lepšie obstát' v selektívnych procesoch. Vd’aka opakujúcim sa koevolučným interakciám došlo $\mathrm{k}$ vytvoreniu komplexných jazykov a $\mathrm{k}$ tomu, že disponujeme energeticky náročným aparátom, ktorý nám umožňuje ich používat"“ (Boyd, Richerson 2005, 4).

$\mathrm{V}$ jednej stati nie je priestor na to, aby sa v nej venovala adekvátna pozornost' všetkým relevantným prístupom k teórii evolúcie. Rozhodol som sa, že pozornost' upriamim len na jeden pokus explikovat' našu morálku, ktorý je založený na génocentrickom prístupe k evolúcii. Dôvod je ten, že hoci ide o prístup, ktorý je medzi evolučnými biológmi v ostatných rokoch skôr na ústupe, stále platí, že ak sa vo filozofii spomínajú evolučne podmienené morálne normy, tak sa tým zvyčajne myslia normy, ktorým vd’ačíme za vznik procesom, ktoré reflektuje práve génocentrická verzia evolučnej teórie. ${ }^{11}$ No ešte predtým, ako sa $\mathrm{k}$ tomuto pokusu dostanem, by som sa rád stručne venoval otázke, prečo je to, či sú naše normy produktom evolučného vývoja, relevantné z hl'adiska filozofie.

\footnotetext{
${ }^{10}$ Pre túto teóriu pozri Boyd, Richerson (2005).

${ }^{11}$ Spomedzi filozofov génocentrický pohl’ad na evolúciu zastávajú napríklad Daniel Dennett (1995, 58), Philip Kitcher (2003) alebo Joshua Greene (2013). Za povšimnutie tiež stojí, že existenciu prírodného výberu na úrovni génov predpokladá aj Wilsonova teória skupinového výberu a teória podvojnej dedičnosti, len s tým rozdielom, že podl'a týchto teórií prírodný výber prebieha aj na iných úrovniach.
} 


\section{Relevantnost' $\mathbf{z}$ hl'adiska filozofie}

Je niekol'ko dôvodov, prečo je otázka, či sú naše normy produktom evolučného vývoja, relevantná z hl'adiska filozofie. Napríklad podla Street (2006), ak sa nemýlime $\mathrm{v}$ tom, že naše normatívne postoje sú produktom evolučného vývoja, tak to predstavuje vážny problém pre realistické pozície, podl’a ktorých nezávisle od nás existujú dané, poznatel'né normatívne fakty alebo normatívne pravdy. Realisti by totiž vd’aka tomu stáli pred nel'ahkou úlohou vysvetlit', „... aký je vzt'ah (ak vôbec nejaký je) medzi selektívnymi mechanizmami, ktoré ovplyvnili podobu našich normatívnych postojov a nezávisle na nás danými normatívnymi pravdami, ktorých existenciu predpokladajú realisti““(Street 2006, 121).

$\mathrm{Z}$ množstva prác, ktoré si dali za ciel' ponúknut' nové podnety pre etiku vd’aka postrehu, že morálne normy sú produktom evolučného vývoja, môžeme spomenút' aj Kitcherovu publikáciu The Ethical Project. Kitcher $(2011,410)$ v nej na základe toho, že sa na morálku pozerá ako na nedokončený produkt evolučného vývoja, ktorého funkciou je pomôct' nám spolunažívat' a navzájom spolupracovat', dospel k záveru, že by sme v rámci filozofických reflexií namiesto technických otázok mali v spolupráci s inými disciplínami zamerat' pozornost' na hl'adanie spôsobov, ako tento produkt vylepšit tak, aby svoju funkciu vo svetle súčasných výziev a problémov mohol plnit' aj nad'alej.

Otázka, či sú naše normy a správanie evolučne podmienené, je relevantná aj z hl'adiska debát o l'udskej prirodzenosti. ${ }^{12}$ Ako upozorňuje Sedová $(2008,666)$, snahy vysvetl'ovat' tieto fenomény evolučne, vedú $\mathrm{k}$ formulovaniu univerzálií o človeku. Zatial' čo podl'a Wilsona existujú štyri biologicky podmienené kategórie, ktoré ovplyvňuje správanie človeka, a to: agresivita, sexualita, altruizmus a náboženstvo, ${ }^{13}$ v monografii Donald E. Browna (1991) Human Universals je obsiahnutý rozsiahly zoznam takýchto univerzálií (Sedová 2008, 666 - 667). ${ }^{14}$ Avšak, z hladiska debát o l'udskej prirodzenosti nie je ani tak dôležité, kol'ko a akých konkrétnych znakov človeka sa na takýchto zoznamoch nachádza, ale to, či človeka možno vnímat' ako

\footnotetext{
${ }^{12}$ Pre dejinno-filozofický prehl'ad debát o l'udskej prirodzenosti je možné pozriet' (Mihina 2019). Pre zamyslenie sa nad tým, kam by sa debaty o l'udskej prirodzenosti mali posunút' v súčasnosti, je možné pozriet' (Zarka 2018).

${ }^{13}$ Wilson túto myšlienku rozvíja vo Wilson (2004).

14 Tento zoznam sa nachádza v Pinker (2003, 435 - 439). Ide o zoznam, v ktorom možno nájst' všeobecné znaky typu: v každej spoločnosti existujú určité tabu, až po konkrétne morálne normy, ako napríklad odmietanie incestu alebo znásilnenia. Nazdávam sa, že vytváranie takýchto zoznamov čelí úskaliu, že ak sa v ňom nachádzajú dostatočne všeobecne formulované znaky, voči univerzálnej povahe ktorých azda nemožno namietat', je namieste spýtat' sa, či takýto všeobecný znak vôbec hovorí niečo informatívne o človeku. Na druhej strane, pri konkrétnejšie formulovaných znakoch sa vynárajú otázky, či voči nim neexistujú protipríklady. Napríklad schval'ovanie incestu je pomerne dobre podloženým fenoménom v egyptskej spoločnosti antického Ríma (Scheidel 1996).
} 
tvora, ktorý je produktom prírodných biologických evolučných procesov, a to nielen po fyzickej stránke, ale aj po stránke kultúrnej.

Neznamená to však, že na zodpovedanie tejto otázky by nebolo potrebné venovat' pozornost' konkrétnym pokusom o objasnenie nadobudnutia našich kultúrnych prvkov za pomoci evolučného procesu. Aj z tohto dôvodu som sa rozhodol nasledujúcu čast' venovat' teórii s názvom morálka ako spolupráca (morality-as-cooperation), v rámci ktorej antropológovia Curry, Mullins a Whitehouse (2019) predpokladajú, že morálka je súborom biologických a kultúrnych odpovedí na potrebu zabezpečit' spoluprácu v l'udských spoločnostiach.

\section{Morálka ako spolupráca}

Antropológovia Oliver Scott Curry, Daniel Austin Mullins a Harvey Whitehouse (2019) v článku Is it Good to Cooperate? prepokladajú existenciu siedmich morálnych vzorcov naprieč všetkými kultúrami, pričom tento svoj predpoklad podrobujú testovaniu. Vychádzajú z toho, že aby gény l'udí (ale aj mnohých iných živočíchov) neboli prírodným výberom eliminované, bolo pre nich výhodné, ak navzájom vedeli spolupracovat' (Curry, Mullins, Whitehouse 2019, 48). Ked'že l'udia na potrebu spolupracovat' narážali v najrôznejších situáciách, boli nútení osvojit' si nie jedno, ale viacero riešení problému, ako vzájomnú spoluprácu zabezpečit'. Podl’a teórie morálky ako spolupráce ${ }^{15}$ „práve tieto početné riešenia problémov spolupráce — tieto súbory inštinktov, intuícií a inštitúcií — predstavujú našu morálku“ (Curry, Mullins, Whitehouse 2019, 48).

Konkrétne autori identifikujú sedem typov problémov spolupráce, s ktorými sa podl'a nich musí každé spoločenstvo vysporiadat'. Ide o „(1) odovzdávanie zdrojov príbuzným; (2) koordinácia za ciel’om spoločnej výhody; (3) sociálna výmena; a riešenie sporov pomocou zápasu, ktorý zahŕňa (4) jastrabie prejavy dominancie a (5) holubičie prejavy submisivity; (6) delenie sporných zdrojov; a (7) rešpektovanie vlastníctva“ (Curry, Mullins, Whitehouse 2019, 48).

Na základe týchto siedmich problémov spolupráce sa podla týchto autorov dá predpokladat', že v každom spoločenstve nájdeme sedem morálnych vzorcov, ktoré sú založené na tom, že z morálneho hl'adiska sa za správne pokladá týchto sedem typov konaní: (1) pomáhanie príbuzným; (2) pomáhanie vlastnej skupine; (3) uplatnenie reciprocity v otázke vynakladania nákladov a dosahovania zisku; (4) ,jastrabie“ prejavy odvahy; (5) ,holubičie“ prejavy submisivity voči vodcom a autoritám; (6) delenie

${ }^{15}$ Morálka ako spolupráca (morality-as-cooperation) je názov teórie morálky, ktorú autori daného článku zastávajú. 
sporných zdrojov; (7) rešpektovanie vlastníctva (Curry, Mullins a Whitehouse 2019, 48). ${ }^{16}$

Ciel'om výskumu daných autorov bolo pomocou etnografických záznamov šest'desiatich skúmaných spoločností zistit', ako členovia daných spoločností uvedené typy konaní z morálneho hladiska hodnotia (Curry, Mullins a Whitehouse 2019, 48). Dopracovali sa k výsledku, že v každej skúmanej spoločnosti, v prípade ktorej k danému typu konania existoval dostatok dát, sa ukázalo, že jej členovia daný typ konania zvyknú hodnotit' z morálneho hl'adiska pozitívne, pričom sa nenašli žiadne protipríklady - nenašli sa také spoločnosti, $\mathrm{v}$ ktorých by sa skúmaným typom konania pripisovali negatívne morálne hodnotenia (Curry, Mullins a Whitehouse 2019, 55).

$\mathrm{V}$ tomto článku nie je priestor na to, aby som venoval samostatnú pozornost' každému zo siedmich spomínaných problémov kooperácie a tomu zodpovedajúcim morálnym vzorcom. Pristavím sa iba pri bodoch 4. a 5., ktoré sa týkajú boja o zdroje, pretože sa nazdávam, že evolučné vysvetlenie nadobudnutia týchto morálnych vzorcov, ktoré autori spomenutého článku ponúkajú, stojí minimálne za diskusiu.

Podl'a jeho autorov teória morálky ako spolupráce nás vedie $\mathrm{k}$ tomu, aby sme očakávali, že tieto typy kooperatívneho správania — ,jastrabie“ prejavy dominancie (,heroické cnosti“ odvahy, sily, šikovnosti a prefíkanosti) a „holubičie“ prejavy submisivity („,mniśšske cnosti“ pokory, poddajnosti, poslušnosti a úcty) — budú považované z morálneho hladiska za správne“ (Curry, Mullins a Whitehouse 2019, 49). ${ }^{17}$ Korene tejto skutočnosti majú spočívat' v tom, že každé živočíšne spoločenstvo muselo nájst' spôsob, ako sa vysporiadat' s konfliktmi o jedlo, teritórium a sexuálnych partnerov (Curry 2007, 252). Jedným zo spôsobov, ako sa s tými konfliktmi vysporiadat', je zápas. Tento zápas však nemusí tkviet' priamo vo fyzickom boji o zdroje, ale „len“ v tom, že účastník konfliktu dá najavo svoju schopnost' a ochotu bojovat' (prejaví odvahu). V ideálnom prípade potencionálny súper vd’aka tomuto prejavu z boja vycúva. Vyriešenie konfliktu takýmto nekrvavým spôsobom je často pre obe strany konfliktu z hl'adiska šance odovzdat' gény nasledujúcim generáciám výhodnejšie ako nebezpečný boj. $Z$ tohto dôvodu nič nebránilo tomu, aby sa táto prax nekrvavého riešenia konfliktov postupne ,inštitucionalizovala“ tak, že v prípade mnohých živočišnych druhov vrátane človeka došlo k vytvoreniu hierarchií, čiže k deleniu jednotlivcov, obrazne povedané, na dominantné ,jastraby“ a submisívne „holubice“

\footnotetext{
${ }^{16} \mathrm{~K}$ týmto siedmim typom konania by sa dalo vytvorit' sedem protikladných typov správania (zanedbávanie príbuzného, zrada iného člena skupiny, správanie ako čierny pasažier, zbabelost', neúcta voči vodcom a autoritám, nespravodlivé delenie zdrojov, krádež), o ktorých spomínaní autori očakávajú, že budú v každej kultúre prostredníctvom morálky odmietané (Curry, Mullins a Whitehouse 2019, 50). Tento svoj predpoklad však už netestujú.

17 Termíny ,jastraby“ a ,holubice“ začali týmto technickým spôsobom ako prví používat' Smith a Price (1973).
} 
(Curry, Mullins a Whitehouse 2019,49). Naša morálka, v rámci ktorej sa spomínané cnosti „jastrabov“ a „holubíc“ pokladajú z morálneho hladiska za správne, majú dodržiavaniu tohto nekrvavého riešenia boja o zdroje napomáhat' (Curry 2007, 252). Inými slovami, morálka má okrem iného zabezpečovat' to, aby sa ,jastraby“ chceli správat' ako ,jastraby“ a aby sa „holubice“ chceli správat' ako „holubice“.

Netvrdím, že na predstavených dôvodoch, ktoré podl'a autorov viedli k vzniku hierarchií v spoločnostiach, nič nie je, ale jedna vec je tvrdit', že sme evolučne podmienení správat' sa v závislosti od situácie dominantne alebo submisívne, druhá vec je tvrdit', že sme evolučne podmienení takéto správanie pokladat' z morálneho hladiska za správne. Ako problém sa mi javí to, že hoci teória morálky ako spolupráce ponúka funkcionalistické vysvetlenie nadobudnutia daných prvkov morálky, tieto prvky morálky nie sú pre zabezpečovanie funkcií, ktoré im spomínaná teória pripisuje, nevyhnutné. $Z$ teórie morálky ako spolupráce totiž vyplýva, že pozitívne morálne hodnotenia prejavov dominancie a submisivity zohrávajú významnú úlohu v boji o zdroje a pri ich delení. Existuje ale množstvo živočíšnych druhov, ktoré prostredníctvom prejavov dominancie alebo submisivity zápasia o zdroje bez toho, aby na to potrebovali morálku, ktorá by cnosti, ktoré s týmito prejavmi súvisia, nejakým spôsobom z morálneho hladiska pozitívne hodnotila. ${ }^{18}$ Po príklady však vôbec nemusíme zachádzat' do živočíšnej ríše. Aj v našej kultúre totiž platí, že vlastnosti ako „byt' silný“ alebo „byt' krásny“ síce zohrávajú významnú úlohu v boji o zdroje, vrátane „boja“ o sexuálnych partnerov, no ktorým žiadne morálne hodnotenia nepripisujeme. Azda každý z nás chce byt' fyzicky silný a krásny (chce byt' pomyselným jastrabom), no napriek tomu si nezvykneme mysliet', že ak niekto disponuje týmito vlastnost'ami, tak je z morálneho hl'adiska lepši ako ten, kto týmito vlastnost’ami neoplýva. ${ }^{19}$

Ak teória morálky ako spolupráce predpokladá, že pripisovanie pozitívneho morálneho hodnotenia určitým vlastnostiam je adaptáciou, ktorú sme nadobudli vd’aka evolučnému vývoju, tak by mala ponúknut' vysvetlenie, prečo disponovanie touto adaptáciou bolo $\mathrm{z}$ hl'adiska šance, aby naše gény neboli eliminované prírodným výberom, výhodné. Obávam sa, že teória morálky ako spolupráce žiadne takéto vysvetlenie neponúka a ani ho nemôže ponúknut', pretože z hl'adiska šance, aby naše gény neboli eliminované prírodným výberom, by bolo rovnaké výhodné, keby sme ,jastrabie“ a „holubičie“" cnosti iba preferovali, bez toho, aby sme im pripisovali morálne hodnotenia. Berúc do úvahy teóriu morálky ako spolupráce preto nevidím dôvod,

${ }^{18}$ Aj Curry $(2007,253 ; 255)$ ako príklady takýchto zvierat uvádza jelene a psy.

${ }^{19}$ Curry $(2007,251)$ poukazuje na to, že v minulosti sa zvyčajne pripisovalo morálne hodnotenie aj kráse. Avšak práve s tým súvisí moja otázka: Prečo sa krása nepokladala za niečo, čo je z morálneho hladiska neutrálne, tak ako dnes? Ved' aj bez morálneho hodnotenia môže krása predstavovat' rovnako významné kritérium pri výbere partnera. 
prečo sa na dané prvky morálky pozerat' ako na adaptáciu, a nie napríklad ako len na vedl'ajší produkt evolučného vývoja. Napríklad vedl'ajší produkt toho, že sme biologicky predisponovaní na to, aby v nás určité podnety vyvolávali silné emocionálne reakcie ako hnev alebo znechutenie a toho, že vd’aka evolučnému procesu disponujeme takým mozgom, v ktorého možnostiach je vytvárat' pravidlá, vrátane tých morálnych (Prinz 2007, 270).

V prípade snahy vysvetlit’ pôvod pozitívneho morálneho hodnotenia ,jastrabích“ a „holubičích“ cností prostredníctvom toho, že ide o odpoved” na problémy, ktoré so sebou prinášajú boje o zdroje, vyvstáva aj druhý vážny problém, a to ten, že v najstarších lovecko-zberačských spoločnostiach podla všetkého žiadne boje o zdroje neprebiehali. Žili totiž rovnostársky. Presnejšie, žili v takých spoločenských usporiadaniach, v ktorých „členové se prŕliš neliší v úrovni „bohatstvi““ (stejně je zde pouze málo osobního majetku) a politické moci, s výjimkou důsledků individuálních rozdílů ve schopnostech nebo osobnosti, které ale zmírňuje rozsáhlé sdílení zdrojů všemi členy tlupy“ (Diamond 2014, 26). ${ }^{20}$ Antropológ Kelly (2013) dodáva, že malé majetkové rozdiely členov rovnostárskych lovecko-zberačských spoločností boli len dôsledkom toho, že považujú za vel'mi dôležité, aby „každý mal možnost' dosiahnut' prestíž a aby vynucovanie kultúrnych noriem zabraňovalo tomu, aby niekto mohol nadobudnút' prestíž využit' pre získanie moci nad niekým iným“ (Kelly 2013, 244). Navyše sa zdá, že členovia najstarších lovecko-zberačských spoločností nezvádzali nejakú formu zápasu ani len o sexuálnych partnerov. Podl’a Kellyho (2013, 237 -238) totiž častou praxou, vd'aka ktorej muž $\mathrm{v}$ takýchto spoločnostiach nadobudol manželku, bolo, že bud' si ju po uzavretí manželstva u manželkiných rodičov nejakým spôsobom „odpracoval““, alebo ju získal po odovzdaní určitých symbolických štandardizovaných darov.

Je síce pravda, že existovalo aj vel’a nerovnostárskych lovecko-zberačských spoločností, v ktorých „elity vlastnili otrokov, bojovali vo vojnách a otvorene chceli nadobudnút' prestíž“ (Kelly 2013, 241), avšak podl'a Kellyho archeologická evidencia naznačuje, že takéto spoločnosti sú vývojovo mladšie ako tie rovnostárske (Kelly 2013, 248). Ak použijeme Diamondom preferovanú terminológiu: rovnostársky žili tzv. tlupy, ktorých vel'kost' nepresahovala niekol'ko desiatok jedincov (Diamond 2014, 26), sociálna stratifikácia sa začala objavovat' až s príchodom kmeňov, ktoré disponovali stovkami až tisícmi členov. Na základe toho môžeme usudzovat', že človek strávil ovel'a dlhšie obdobie svojho evolučného vývoja v prostredí egalitárnych malých spoločností, ktoré k vzniku biologicky podmienenej morálky, ktorá by regulovala, ako majú prebiehat' boje o zdroje, nemala ako napomáhat'.

${ }^{20}$ Diamond (2014) vo svojej knihe zo spoločností typu tlupy najčastejšie venuje pozornost' Kungom, ktorí dodnes žijú v blízkosti africkej púšte Kalahari. 
V neposlednom rade by som chcel uviest', že problematický môže byt' aj sám predpoklad existencie vzájomnej podmienenosti medzi našou genetickou výbavou a správaním, ktorý je aj súčast'ou teórie morálky ako spolupráce. Autorom, ktorý polemizuje s názorom, že od génov závisí podoba našich mozgov, a teda aj nášho správania, je John Dupré (2001). Podl'a neho je toto presvedčenie príliš zjednodušujúce. Tvrdí: „Samozrejme, gény samy osebe nedokážu vytvorit’ mozog. Pre vytvorenie mozgu je potrebné, aby gény boli správne umiestnené v bunke a aby zároveň správne pracovali všetky mimobunkové mechanizmy; takisto bunka musí byt' správne umiestnená v maternici ženy; a diet’a sa musí narodit' do sociálneho prostredia, ktoré organizmu disponujúcemu mozgom poskytne nesmierne komplexný súbor stimulov“ (Dupré 2001, 29). Gény sú teda podla Duprého len jedným z mnohých kauzálnych faktorov, ktoré majú vplyv na podobu mozgu, pričom dodáva, že ked'že l'udské mozgy, ktoré vznikli v období pleistocénu (v období, ked' sme mali nadobudnút' najväčší počet adaptácií) vznikli v celkom iných podmienkach, v akých vznikajú dnes, nemáme dôvod predpokladat', že výsledný produkt bude približne rovnaký (Dupré 2001, 31).

Duprého postreh možno preniest' aj na snahy pomocou evolučnej teórie objasnit' pôvod našich morálnych noriem. Môžeme predpokladat', že vd'aka prírodnému výberu disponujeme génmi, ktoré nám prostredníctvom toho, že ovplyvňujú stavbu našich mozgov, umožňujú osvojit' si určité morálne normy. Na ich podobu má však značný vplyv sociálne prostredie, $v$ ktorom jedinec vyrastá a žije. ${ }^{21} \mathrm{Z}$ tohto dôvodu sa nazdávam, že adaptáciou by mohli byt' maximálne naše biologické predpoklady osvojit' si nejaké morálne normy. Na podobu morálnych noriem má sociálne prostredie príliš vysoký vplyv na to, aby sme ich mohli pokladat' za nejakú formu biologickej adaptácie.

\section{Záver}

Napriek tomu, že môže byt' lákavé hl'adat' evolučné vysvetlenia našich morálnych noriem, treba sa pokúšat takéto vysvetlenia aj kriticky preverovat'. V prípade pokusov explikovat' našu morálku za pomoci teórie morálky ako spolupráce pokladám za nedostatok, že napriek úsiliu, nepodáva vysvetlenie toho, prečo v prípade l'udí dospel prirodzený výber $\mathrm{k}$ tomu, že určitým prejavom dominancie a submisivity pripisujeme morálne hodnotenia. $Z$ hladiska šance, aby naše gény neboli eliminované prírodným výberom, by bolo predsa rovnako výhodné, keby sme ,jastrabie“ a „holubičie“ cnosti síce preferovali, ale nepripisovali by sme im žiadne pozitívne morálne hodnotenia. $\mathrm{Z}$ tohto

${ }^{21}$ Značný vplyv sociálneho prostredia na podobu našich noriem je osobitne badatel'ný na príklade tzv. vlčích detí, ktoré z najrôznejších dôvodov vyrastali v spoločnosti zvierat alebo v izolovanom prostredí. Pre vlčie deti pozri napríklad Newton (2014). 
dôvodu v konečnom dôsledku na základe daného vysvetlenia nemôžeme určit', prečo by sme sa na pripisovanie pozitívneho morálneho hodnotenia „jastrabím“a „holubičím“ cnostiam mali pozerat' ako na adaptácie, a nie napríklad ako na vedl'ajší produkt evolučného vývoja.

\section{Literatúra}

BARKOW, J. H., COSMIDES, L., TOOBY, J. (1992): The Adapted Mind. Evolutionary Psychology and the Generation of Culture. New York; Oxford: Oxford University Press.

BELLISARI, A (2008): Evolutionary origins of obesity. Obesity Reviews, 9 (2), 165 - 180.

BOYD, R., RICHERSON, P. J. (2005): The Origin and Evolution of Cultures. New York: Oxford University Press.

BROWN, D. E. (1991): Human Universals. New York: McGraw-Hill.

CURRY, O. (2007): The Conflict-Resolution Theory of Virtue. In: Sinnott-Armstrong, W. (ed.): Moral Psychology. Volume 1: The Evolution of Morality: Adaptations and Innateness. Cambridge - London: MIT Press. $251-262$.

CURRY, O., MULLINS, D., WHITEHOUSE, D. (2019): Is It Good to Cooperate? Testing the Theory of Morality-as-Cooperation in 60 Societies. Current Anthropology, 60 (1), 47 - 69.

DAWKINS, R. (2003): Sobecký gén. Preložil: Vojtěch Kopský, Praha: Mladá fronta.

DENNETT, D. C. (1995): Darwin's Dangerous Idea. Evolution and the Meaning of Life. London: Penguin Books.

DIAMOND, J. (2014): Svět který skončil včera. Co se můžeme naučit od tradičních společností? Preložila: Eva Nevrlá, Brno: Jan Melvil Publishing.

DUPRÉ, J. (2001): Human Nature and the imits of Science. Oxford: Clarendon Press.

FRASER, B. J. (2010): Adaptation, Exaptation, By-Products, and Spandrels in Evolutionary Explanations of Morality. Biological Theory, 5 (3), 223 - 227.

GOULD, S. J., LEWONTIN, R. C. (1979): The Spandrels of San Marco and the Panglossian Paradigm: A Critique of the Adaptationist Programme. Proceedings of the Royal Society B: Biological Sciences, 205 (1161), 581 - 598.

GREENE, J. (2013): Moral Tribes: Emotion, Reason, and the Gap Between Us and Them. New York: Penguin Press.

JOYCE, R. (2006): The Evolution of Morality. Cambridge - London: MIT Press.

KANOVSKÝ, M. (2000): Sociobiológ na l'adovci. Sociológia, 32 (5), 483 - 494.

KELLY, R. L. (2013): The Lifeways of Hunter-Gatherers. New York: Cambride University Press.

KENNAIR, L. E. O. (2002): Evolutionary Psychology: An Emerging Integrative Perspective within the Science and Practice Psychology. Human Nature Review, 2, 17 - 61.

KITCHER, P. (2003): Philosophical Reflections on Biology. Mendel's Mirror. New York: Oxford University Press.

KITCHER, P. (2011): The Ethical Project. Cambridge: Harvard University Press.

MAYR, E. (2002): What Evolution is? London: Basic Books.

MIHINA, F. (2019): Patrí skúmanie l'udskej prirodzenosti medzi antropologické insolubilia? Filozofia, 74 (4), 318 - 333. DOI: https://doi.org/10.31577/filozofia.2019.74.4.5

NEWTON, P. (2014): Savage Girls and Wild Boys. A History of Feral Children. New York: Picador. PINKER, S. (1998): How the Mind Works. London: Penguin Books.

PINKER, S. (2003): The Blank Slate. London: Penguin Books.

POPPER, M. (2003): Evolučná psychológia a štandardný model sociálnych vied. Filozofia, 58 (1), $10-22$.

PRINZ, J. (2007): The Emotional Construction of Morals. Oxford: Oxford Universtiy Press. 
PRINZ, J. (2008): Is morality innate? In: Armstrong, W. S. (ed.): Moral Psychology. Volume 1: The Evolution of Morality: Adaptations and Innateness. Cambridge - London: The MIT Press, $367-406$.

RUSE, M. (1998): Taking Darwin Seriously: A Naturalistic Approach to Philosophy. New York: Prometheus Books.

SCHEIDEL, W. (1996): Brother-sister and Parent-child Marriage Outside Royal Families in Ancient Egypt and Iran: A challenge to the sociobiological view of incest avoidance? Ethology and Sociobiology, 17 (5), $319-340$.

SEDOVÁ, T. (2000): O jednom pohl'ade na sociálne. Sociológia, 32 (1), 123 - 130.

SEDOVÁ, T. (2008): K pojmom l'udskej prirodzenosti a kultúry a $\mathrm{k}$ ich funkcii v sociálnom poznaní. Filozofia, 63 (8), 657 - 669.

SMITH, J. M., PRICE G. R. (1973): The Logic of Animal Conflict. Nature, 246 (2), 15 - 18.

STREET, S. (2006): A Darwinian Dilemma for Realist Theories of Value. Philosophical Studies, 127 (1), $109-166$.

SÝKORA, P. (1999): Bojí sa sociológia biológie? Sociológia, 31 (4), 375 - 396.

WILSON, E. O. (2000): Sociobiology. The New Synthesis. Cambridge - London: The Belknap Press. WILSON, E. O. (2004): On Human Nauture. Cambridge - London: Harvard University Press.

WILSON, D. S., WILSON, E. O. (2008): Evolution "for the Good of the Group": The process known as group selection was once accepted unthinkingly, then was widely discredited; it's time for a more discriminating assessment. American Scientist, 96 (5), 380 - 389.

ZARKA, Y. CH. (2018): Má ešte pojem l'udská prirodzenost' zmysel?. Filozofia, 73 (10), 777 - 789.

Táto práca bola podporená Agentúrou na podporu výskumu a vývoja na základe Zmluvy č. APVV18-0122.

Stanislav Spodniak

UMB v Banskej Bystrici

Katedra filozofie

Tajovského 40

97401 Banská Bystrica

Slovenská republika

e-mail: stanislav.spodniak@umb.sk 